\title{
POTENTIAL SOLUTIONS FOR CHAOTIC ALIGARH CITY TRAFFIC MANAGEMENT SYSTEM
}

\author{
M Y Khan', M Reza', M S Alam³, M K Vakil', A Talib \\ ${ }^{I}$ M.Tech, Department of Civil Engineering, Al-Falah University, Haryana, India \\ ${ }^{2}$ Asst Professor, Deptt of Civil Engineering, Al-Falah University, Haryana, India \\ ${ }^{3}$ Associate Professor, Department of Electrical Engineering, AMU, UP, India \\ ${ }^{4} M . T e c h$, Department of Civil Engineering, AMU, UP, India \\ ${ }^{5}$ M.Tech, Department of Civil Engineering, IIT Delhi, Delhi, India
}

\begin{abstract}
The ongoing smart city endeavor in India has to address many challenges related to urbanization, traffic congestion, improper public transportation and pollution. There is an urgent need of cutting edge innovations to solve these problems. It is generally observed that in these underdeveloped cities the traffic becomes uncontrollable due to certain well known reasons much as the traffic jam at city major road intersections, roaming vendors, unmanaged parking, improper roadway designs and also the lack of public awareness. In this paper the data were collected to study the above specified problems were observed for the civil lines area of Aligarh city the information so obtained was analyzed on the grounds of traffic flow at major road intersections, the problems of road design and traffic literacy also considered. On the basis of observations made and the collection of enough data, a model is proposed to combat the peak traffic flows at intersections by implementing a time bound system for vehicles. A scheme for traffic diversion for highly congested road intersection of civil lines area is proposed. The data obtained also represent in the form of bar diagram. Suggestions are given for the formation of well-defined channels to facilitate the smooth flow of improvised and eco-friendly public transport. A proposal for the pollution free vehicles like solar energy\& battery based rickshaws is also proposed. Furthermore, a different parking and vendors management solutions are proposed based on the classification of road and traffic conditions at different places. Finally a brief discussion is made about roadway design pattern for such cities to meet the traffic management demands for a smart city.
\end{abstract}

Keywords: Traffic congestion, internal transportation, parking management

\section{INTRODUCTION}

Smart mobility is a key consideration for smart city which includes the development of sustainable, efficient, flexible and technically advanced transport system. This transport system includes reducing pollution, reducing traffic congestion and trip time, multi-service communications, time-cost saving, empowering people with choice and control.

Accessibility generally refers to physical access to goods, services and destinations, which is what people usually mean by transportation. Limited access roads have minimal connections to adjacent properties, while local roads provide direct access. Access management involves limiting intersections and driveways on highways[1].

Due to the lack of integrated transport and land use planning, development projects are made and implemented without carrying out the economic, social and environment impact studies. The haphazard land use and suburbanization has also created a spatial mismatch between jobs location (being concentrated in CBD) and residential location (in suburbs) making it difficult for public transportation to serve efficiently. The equitable and sustainable urban development needs an urban transportation system and land use pattern that can keep a balance between transport supply and demand, which is not possible without Integrating comprehensive transportation planning and master plan.

The annual cost of traffic congestion as of 2013 was $\$ 121$ billion for wasted fuel, time lost and vehicle emissions[2]. In 2013 , traffic congestion robbed the U.S. economy of $\$ 124$ billion. According to an in rix study, this cost is expected to increase by $50 \%$ to $\$ 186$ billion by 2030 . So to reduce this emission there is a need to improve local as well as national accessibility through smart and sustainable solutions.

To control traffic at city's intersections, the use of active RFID technology to automatically detect and manage road traffic congestion in near real-time is very significant, since it is reliable, cost effective and easily manageable. Moreover, this method provides not only the comprehensive way of congestion detection but also manage the traffic flow[3].

Nowadays, global energy and environment are facing vast challenges. In the context of energy internet, transport fleet is transitioning to electric, plug-in and fuel cell vehicles and energy utilization are greener. Electric vehicles (EVs) are becoming popular because of their capability of reducing fuel consumption, emissions and ability to increase the penetration of renewable energy sources into the 
transportation sector. The use of electric energy from renewable resource will reduce the transport share of total energy consumption to less than $1 / 10$ of energy production[4].

Car parking is becoming a major problem with increasing vehicle size and confined parking spaces in urban cities. Searching for a parking space is a routine and often frustrating activity. This activity burns about one million barrels crude oil per day. Smart Parking could result in 2,20,000 gallons of fuels saving till 2030 and approx. $3,00,000$ gallons of fuels saved by 2050 , if executed successfully according to a report. Smart Parking systems obtain information about available parking spaces in a particular geographic area. It involves using real-time data collection, low-cost sensors, and mobile-phone-enabled automated payment systems that allow people to reserve parking in advance or very accurately predict where they will likely find a spot(Smart parking, 9-10-2016).

Other smart strategies include integrated transit hubs, public transport monitoring, single fare card, and real time traffic lights(Transportation, 12-10-2016).

\section{LOCAL MOBILITY MANAGEMENT AND}

\section{ANALYSIS}

From 2011 census report the population of Aligarh city is 874408 and by 2021 it is expected to rise up to 1173501 . By 2020the number of vehicles on our urban roads will increase by 5 times.Utilizing Smart Cities experience and technology accessible around the world, India can drive the much needed transformation to a nation of Smart Cities[7]. Some important facts considering strength and weakness of Aligarh city are given below.

Strength: Availability of land for future use and one of the important business and educational center for utter Pradesh

Weakness: Inadequate transportation facilities, Road quality pattern and design are poor and unplanned, No separate market for vegetable and fruits sellers leading to unavailability of parking space for vehicles, Unplanned infrastructure

\subsection{Area Map Construction}

With the help of Google map, lines are constructed for indicating different roots, location and mark places for a selected area of Aligarh city as shown in Fig 1.Similarly alphabets and numbers indicate different roads and areas of this zone.

Map also consists of three different color lines based on the condition of traffic for that particular road. Red Line indicates the roads having high traffic in the peak hour time.Blue lines indicate the roads which could help in controlling congestion at peak hour time by one way traffic stretegy, mostly these lines provide connection for residential areas to the main road. Green line shows roads having smooth traffic flow.

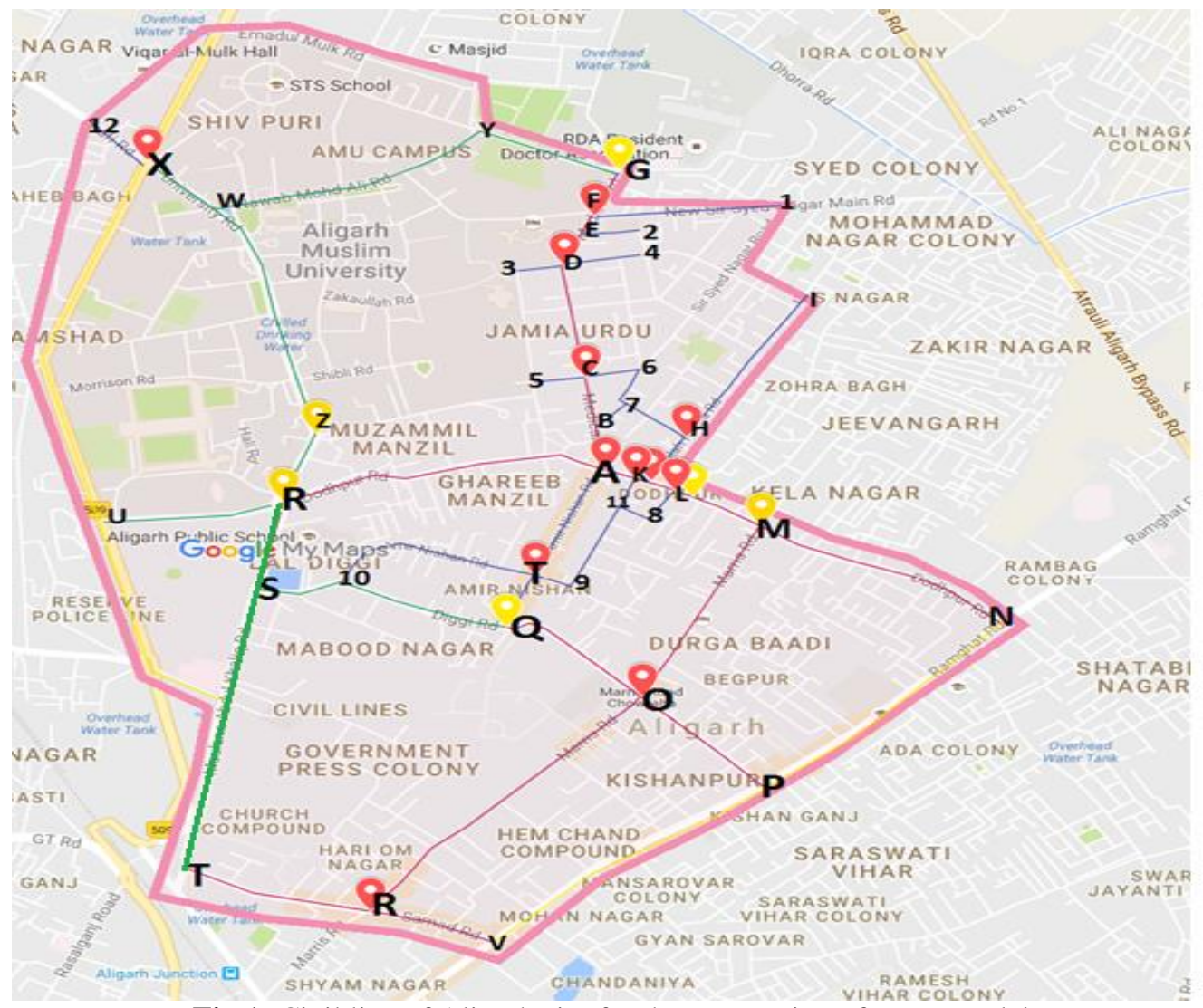

Fig 1: Civil line of Aligarh city for the preperation of smart model 


\subsection{Road Width Determination}

As local or internal accessibility plays a key role for a city renovation towards smartness, so it is necessory todetermine the road width and rectify the problem associated with traffic jam and internal congestion at all.

For 20 appreciably high crowded locations of the city, the road widths were measured ranging from $9.6 \mathrm{ft}$ to $31 \mathrm{ft}$. The mean width is $17.12 \mathrm{ft}$ and the standard deviation has come out to be $5.65 \mathrm{ft}$ which shows the non-uniformity while deciding the road widths at crowded locations. Nonuniformity of the roads results in unexpected traffic jams at roads having comparatively lesser width.

\subsection{Traffic Survey, Problems and Solutions at}

\section{Critical Crossings}

On the basis of periodical traffic surveys done during peak hours i.e. $1 \mathrm{pm}$ to $3 \mathrm{pm}$ of location A of Fig 1, the collected data is shown in Error! Reference source not found., which point outs the percentage of traffic flow from a specific point towards three different directions. From the histogram in Fig 2 and Fig 3the following information is extracted:

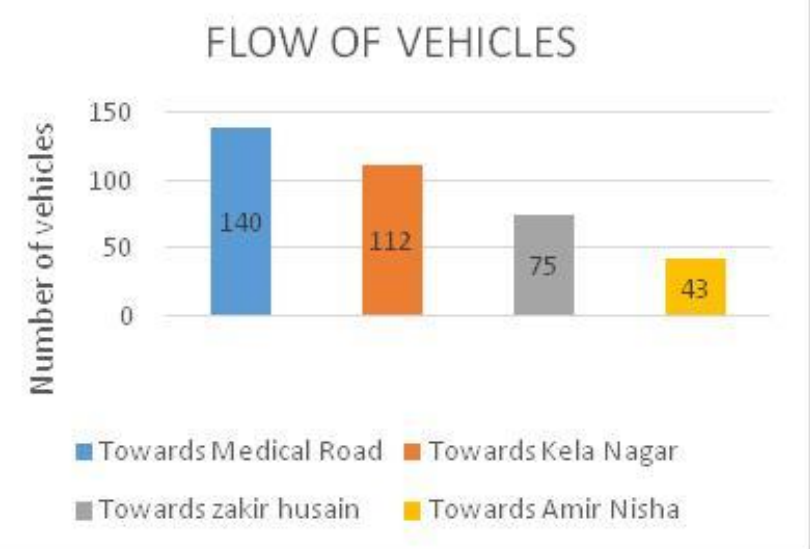

Fig 2: Number of vehicles flow from a point towards three different ways

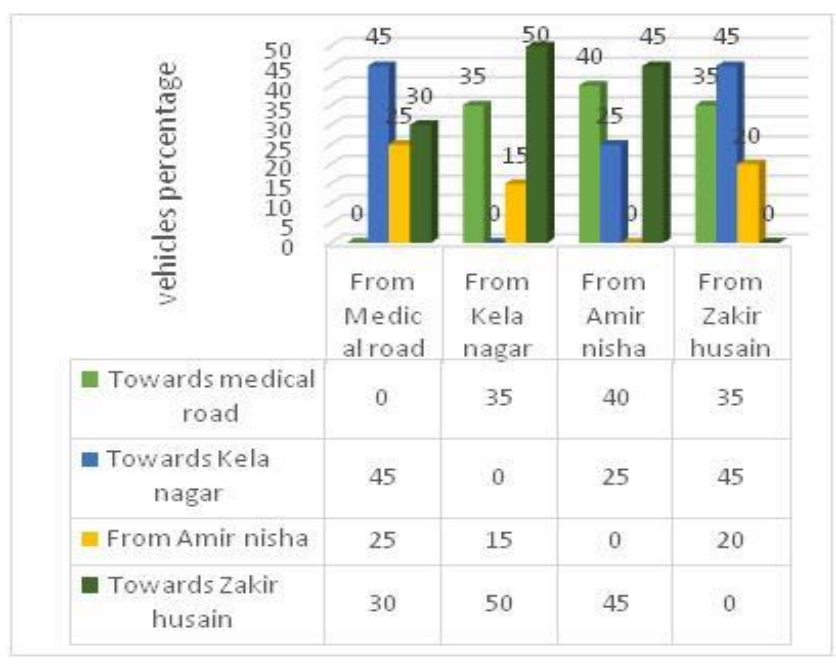

Fig 3: Percentage of traffic flow from a point towards three different ways

Location $\mathrm{A}$ is the most critical intersection of the projected area in terms of traffic jam, high level of rush on street at peak hours. The roads are small in width for the given traffic.

The graph in Error! Reference source not found. shows the non-uniformity of traffic over different routes at peak timings. If static traffic lights are installed, then they would not be able to count the number of vehicles and prioritize the vehicle types. As a result, some vehicles would have to wait even when there is no traffic on the other side. After observing and analyzing this problem, the installation of RFID technology based Traffic Signals seem to be the best way of tackling the existing traffic problems. The flow rate of traffic also depends upon various factors like route diversions, encroachment, dividers, pedestrian, and types of transportation running, Roadside vendors and unauthorized parking lots which are discussed as follows:

1. As shown in Fig 1 the roads A-T and A-B have no side Krebs across while road A-K and A-R have some side spaces, it is necessary to plan these margins and pavement as per the Indian standards.

2. Observed peak hour timings are from 1-3 pm and 5-8 $\mathrm{pm}$. For this specific time, closing of the incoming traffic from road A-T is a very good solution. It is found from the survey that about $95 \%$ vehicles moving in or out on the road A-T are two wheelers or three wheelers. This traffic can pass at that time through T-9-11-K or T$10-\mathrm{S}$, or can move back through T-Q. Also during these peak timings, the vehicular movement should occur through C-5 or C-6 via 6-7-H-K. Simultaneously, the incoming traffic through 5-C and 7-C should be ceased, and to control traffic flow at $\mathrm{K}-\mathrm{H}$, the four wheelers should be stopped from moving through K-H. This step would provide a greater accessibility without any cost. To enforce these regulations, smart traffic lights system can be applied which includes the function of selftraffic flow deduction and real time control based management.

3. There are electric poles near point $\mathrm{A}$, which create hindrance in traffic flow, so it is necessary to place them on extreme right of the road or underground cabling is an alternative solution.

4. Parking is also an important problem for this area as there is no space provided yet to park the vehicle. Conferring to present condition of the area, no other option remains except to increase the width of road and demolition of side construction with rebuilding underground parking facilities or make available space for parking.

5. The city development authority should keep their supervision over roadside markets and buildings to stop plan violation.

6. Vendors should be strictly prohibited at side of the road, separate market should be made for these vendors as discussed in 0 .

7. The width of each road connected to this crossing should be uniform at all points. 
8. Smart traffic signals should be applied based on active RFID technology.

9. The school buses which pass in peak hours should not be allowed to enter in the red line area as shown in Fig 1 in peak hour timings.

10. Vehicle parking should be prohibited up to 30 meters from each side of roads near intersection.

11. Traffic literacy must be encouraged among citizens.

12. Construction of traffic rotary at necessary intersections to avoid traffic interference.

\subsection{Solar E-rickshaw: A Smooth and Eco-friendly}

\section{Internal Transport System}

Generally, in cities like Aligarh, people of different age groups have varying possibilities of having their personal vehicles to drive alone. A survey has been carried out over 100 permanent residents of Aligarh; see Table 1, where it is observed that the age group of 15 to 30 owns the maximum percentage of vehicles comparatively to other groups. The data also shows that the age group of 55+ is appreciably dependent upon Public Transportation. The age groups of 6 to 15 and 15 to 30 are easy to get learned about the traffic literacy and environmental pollution caused by automobiles. If proper trainings were given to people then it is possible to transform the personal mode of transport for age groups 6 to 15 and 15 to 30 to public mode of transport. In order to deploy an approachable, time saving, eco-friendly, sustainable and easy local transport mode, the single stop solution is Solar Energy based e-Rickshaw of intercity people it is find out that mostly low income people, senior citizens, women and some students prefer internal transport through rickshaw hence to improve internal accessibility it is necessary to introduce a fast and smooth solar e-rickshaw transport system.

Table 1: Survey in between 100 people of different age groups when travels alone

\begin{tabular}{|l|l|l|}
\hline Age & $\begin{array}{l}\text { Public } \\
\text { transport\% }\end{array}$ & $\begin{array}{l}\text { Own } \\
\text { vehicle \% }\end{array}$ \\
\hline $6-15$ & 90 & 10 \\
\hline $15-30$ & 18 & 82 \\
\hline $30-55$ & 39 & 61 \\
\hline $55+$ & 68 & 32 \\
\hline
\end{tabular}

A model of design routes and station for fast and flexible movement of e-rickshaw is given in Fig 4 which can be described as follows.

1. Through red line Station A will cover area 3 while station B cover area 2 ,

2. Green line will cover area near point $12,13,14,15,16$ through station D

3. The yellow line will cover area $1,4,5,6,7,8,9,10$ through station $\mathrm{C}$

4. The card swapping, Paytm and other facilities can also be made available with every vehicle so that the passenger can pay in easily and in a fast way.

5. At every station solar based charging slots would be available.

6. Phone call facility should also be provided at every station so that people can call the rickshaw at their address in case of any emergency or for providing services to handicap and old people. Extra charge could be applied for this additional service

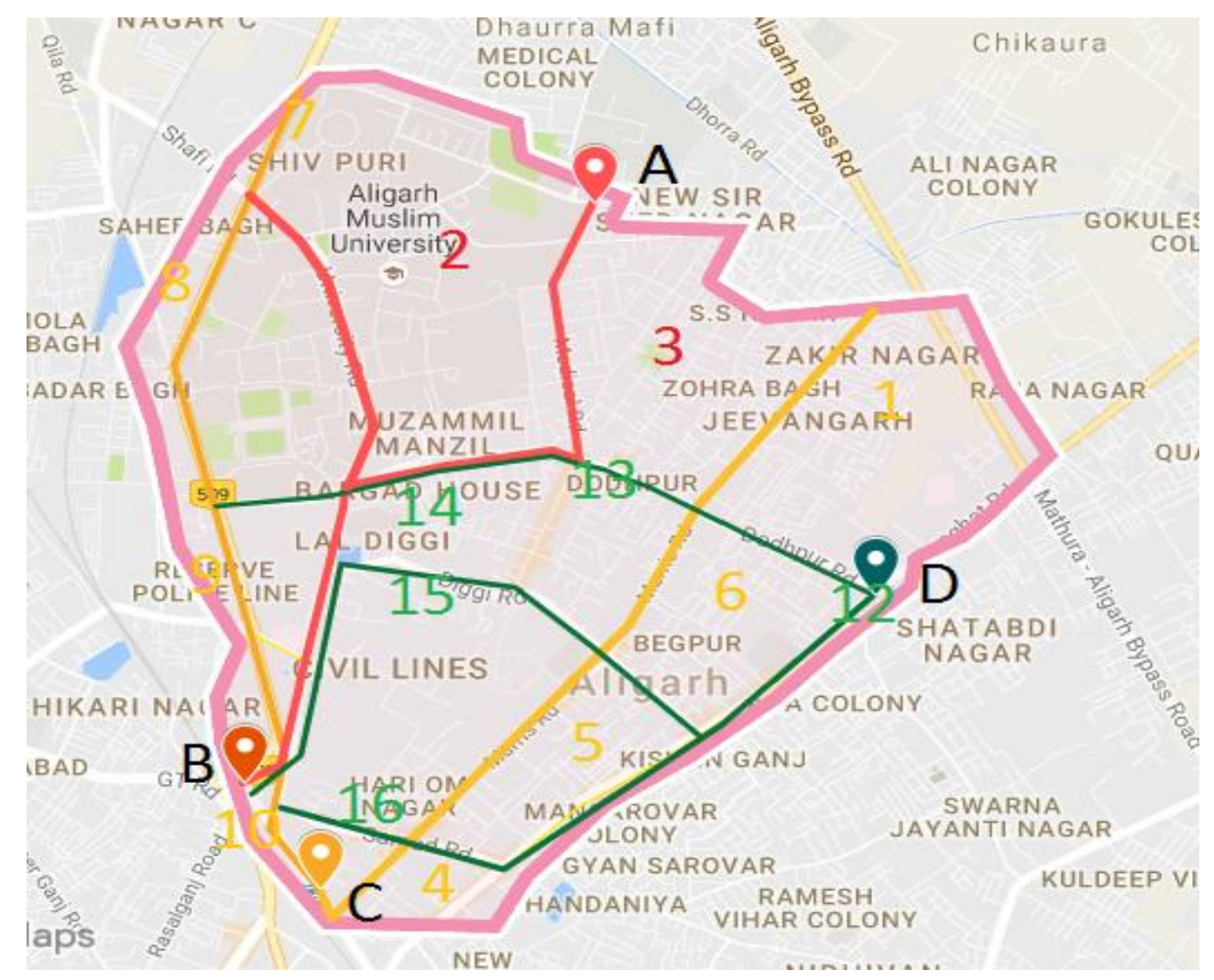


Fig 4: Different zones indicatedby colored lines for e-rickshaw movement withA, B, C, D their respective stations

\subsection{Parking Management}

In sectionError! Reference source not found. The system of smart parking is discussed. In recent technological advancement it is easy to find parked vehicle using various mobile based technologies such as Google map, the only need is to find the accurate parking location for a vehicle,
Civil lines area contains four kinds of roadways, based on traffic conditions and road width.

Based on the width and traffic condition of different roads shown in Fig 5, an improved parking system is proposed for the civil line and nearby areas. Solutions based on the color coding of different routes are briefly explained below:

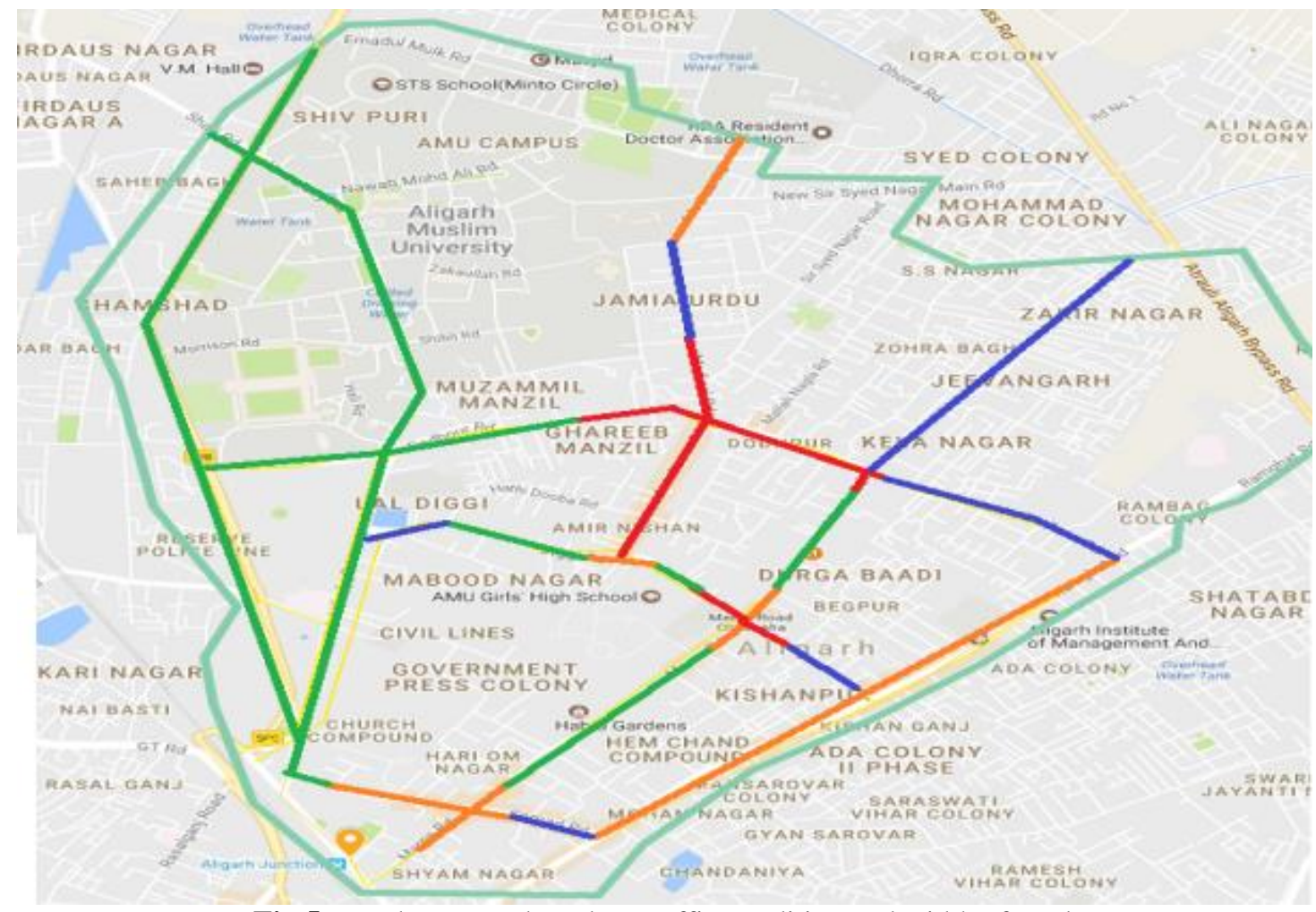

Fig 5: Roadway map based on traffic condition and width of road

RED LINE: Narrow road way and high traffic area

- Red line areas specially near Civil lines have no other option except to increase inroad width and demolition of road side illegal construction

- Underground parking facilities should be incorporated in the existing constructions.

- If underground parking is not possible than all residence, shopping points, offices, hotels and other building complexes should first specify parking areas with respect to their buildings.

- Approval for any building should be canceled out immediately if it is unable to show separate space for parking

ORANGE LINE: Wide roadway and high traffic area

- In Orange line areas demolition is not required, infect parking areas should be predefined for public by city transport department, so that no one can park their vehicles anywhere outside the parking area.

- For these areas the road side parking space can be provided but not in continuous manner. It should be at certain distance to avoid traffic jam like condition as shown in Fig 6. Separate sensor for each parked vehicle which remains connected to the mobile devices through IoT should be installed.

BLUE LINE: Narrow roadway and low traffic area

- Blue line areas are the low traffic areas with smaller width of road, so the only option left for parking is to make parking space in front of each building.

GREENLINE: Wide roadway and low traffic area

- Green line areas are very appropriate for parking spots. These areas can be filled with large number of parking spots at side of the road. Inside all red line areas if parking facility is not available or filled than vehicle should be park by people to nearest green zone.

Based on the above discussion a model of road side parking system is drawn as in Fig 6.It is proposed that parking space should be provided in an alternate manner on each side of road after every 50-60 meter distance for two way road. By this strategy, it is easy to reduce the rate of congestion for the vehicles approaching from both sides of the road. 
The sensors provided at every parking space will give information regarding the time of parking, available space for parking etc. using mobile application.

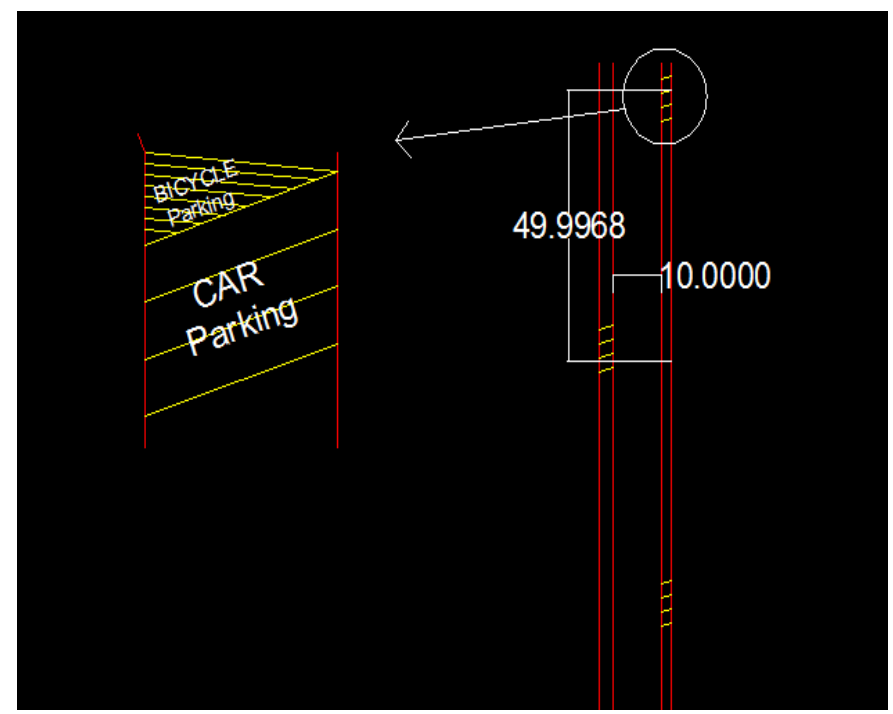

Fig 6: AutoCAD drawing model for road side parking

\subsection{Vendors Management}

This Civil lines area is full of residential places, so it is required to develop a market place for everyday grocery service for vegetable, fruits etc.

In current scenario vendors are placing their stalls on the road to sale products for daily needs, which results in traffic congestion. A solution for this problem could be to setup separate market place within every one kilometer radius area.

Now considering the $1 \mathrm{~km}$ radius for Civil line region, from Goshtwaligali to Barula market there are five different markets of this type, three of them namely Barula market, Aslam market and Akbar market which are appropriate for placing vegetables, fruits and other stalls. So there is no need for temporary shelters, as these three places can be used for this work.

To manage these vendors a home delivery service should be there to be performed by a centralized body which remains connected with all vendors/sellers and receive order from consumers in a particular area. This will help significantly to reduce traffic movement. This will surely stop large number of people from rushing towards the market to buy everyday needs.

\subsection{Pavement Design Aspects}

Some recommended methods for the design of pavement for civil lines are as follows:

a) Currently people of this area use side shoulders for parking and for placing stalls. The current situation of civil line area is shown in Fig 7. It can be clearly seen how side shoulders are being used by people for parking as well as for placing stalls. Electric poles can also be seen creating disturbance.

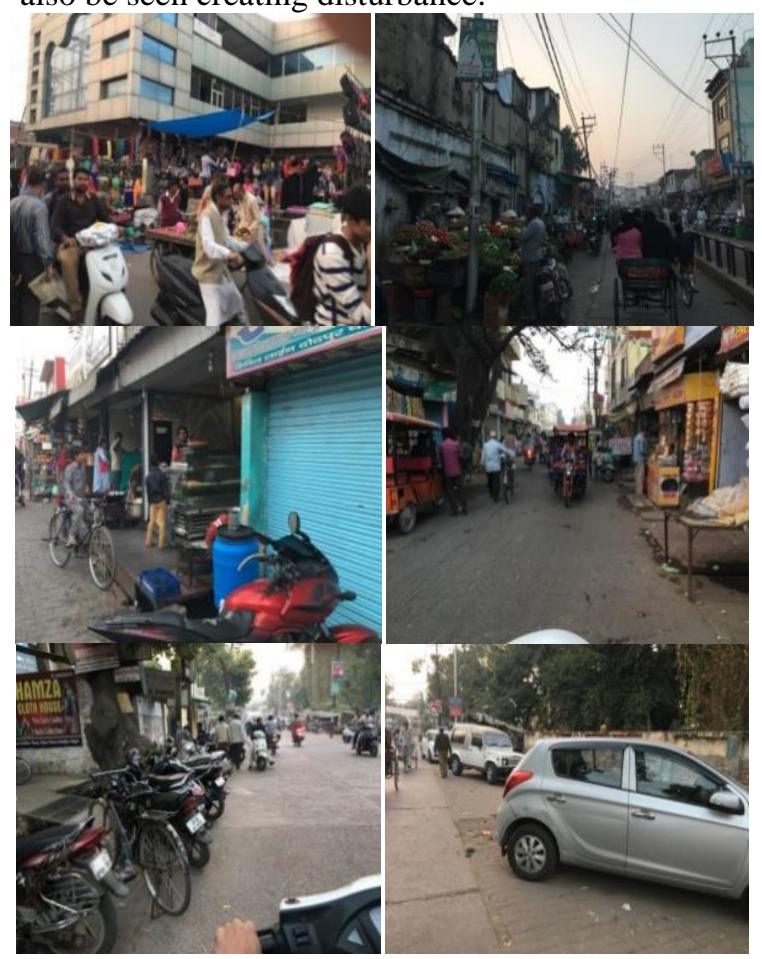

Fig 7: Road side condition of nearby location of point A of Fig 1[20 November 2017]

- First two images show the side shoulders which are currently in use for selling fruits and other vegetables.

- Second two images show how shopkeepers used the sewer cover for their personal work and road A-B-C-D of Fig 1 have lack of side spaces for shoulders.

- The last two images show how people are using road side for parking purpose.

According to IRC086 the lane width for two way road should be 7.5 meters including Krebs, To satisfy this criteria the roads starting from point ' $A$ ' should be extended up to this level, which requires some demolition. The present dimensions of road are shown in Fig 8 while proposed dimensions are given in Table 2. It can be seen the width of each road is smaller than recommend, furthermore there is an absence of proper side spaces for shoulders, Krebs and parking facilities.

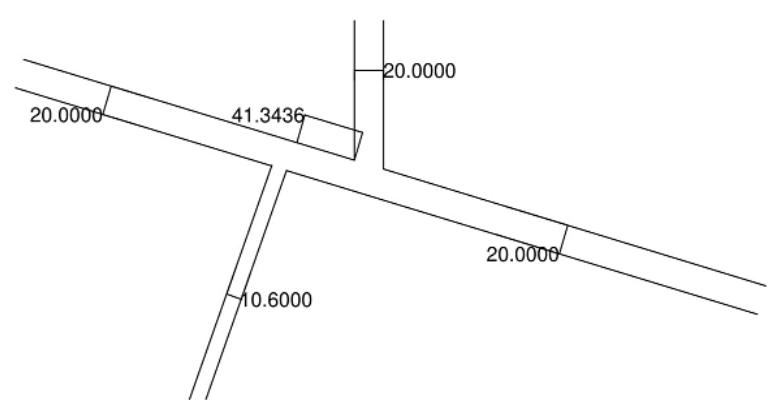


Fig 8: extracted AutoCAD drawing of location A of Fig 1, dimensions are in feet.

Table 2: Dimension of different elements of road

\begin{tabular}{|c|c|}
\hline Side shoulders & $\begin{array}{c}\text { Width } 5 \text { feet \& thickness } \\
1.5 \text { feet }\end{array}$ \\
\hline $\begin{array}{c}\text { Battery rickshaw and } \\
\text { bicycle lane }\end{array}$ & 3.2 feet both side of road \\
\hline Main road & $\begin{array}{c}32.8 \text { feet including } \\
\text { divider and bicycle lane }\end{array}$ \\
\hline Divider & 3.2 feet wide \\
\hline
\end{tabular}

If we will apply the proposed plan then all internal road scan achieve smooth traffic flow and every day traffic jam condition can be decreased up to a satisfactory level.

This is a most simple and practical approach which just requires the demolition of unauthorized and illegally constructed properties.

\section{COST AND BENEFIT ANALYSIS}

To examine the cost and benefits for whole work, analysis is done for one kilometer road patch of civil line area. Table 3 shows the work needed for smooth traffic flow inter the city with total investment involve in each individual work also benefits/results are discussed in different prospect.

Table 3: Cost-benefit analysis

\begin{tabular}{|c|c|c|}
\hline WORK & $\begin{array}{l}\text { NVE } \\
\text { TME } \\
\text { ITS }\end{array}$ & $\begin{array}{l}\text { BENEFITS/ } \\
\text { RESULTS }\end{array}$ \\
\hline $\begin{array}{l}\text { DESIGN OF } \\
\text { ROADWAY } \\
\text { 1. Increase } \\
\text { pavement } \\
\text { width up } \\
\text { to } 3.5 \\
\text { meter to } \\
\text { each side } \\
\text { of the } \\
\text { divider. } \\
\text { One meter } \\
\text { wide } \\
\text { rickshaw } \\
\text { and } \\
\text { bicycle } \\
\text { lane to } \\
\text { each side } \\
\text { of road. } \\
\text { Constructi } \\
\text { on of } 1.0 \\
\text { m wide } \\
\text { divider at } \\
\text { the middle } \\
\text { of } \\
\text { roadway. } \\
\text { Side walk } \\
\text { of } \\
\text { concrete } \\
\text { kerb } 1.5\end{array}$ & $\begin{array}{l}\text { Cost } \\
\text { per } \\
\text { meter } \\
\text { for } \\
11-18 \\
\text { meter= } \\
819 \$( \\
\text { Cost } \\
\text { per } \\
\text { metre } \\
\text { road) } \\
\text { Total } \\
\text { cost } \\
\text { for } \\
1 \text { km } \\
\text { patch } \\
\text { will } \\
\text { equals } \\
5.57 \\
\text { crores } \\
\text { in INR } \\
\text { approx } \\
\text { imatel } \\
\text { y }\end{array}$ & $\begin{array}{l}\text { - In peak hour timing } \\
\text { to cross this one } \\
\text { km patch, a car } \\
\text { take } 20 \text { minutes or } \\
\text { more, now it will } \\
\text { cross within } 5 \\
\text { minutes. } \\
\text { - As less time as } \\
\text { vehicle move on } \\
\text { road it will produce } \\
\text { less harmful gases } \\
\text { in atmosphere such } \\
\text { as NOx, CO2, CO } \\
\text { and hydrocarbons } \\
\text { etc } \\
\text { The annual cost of } \\
\text { traffic congestion } \\
\text { in the year } 2013 \\
\text { was } \$ 121 \text { billion } \\
\text { due to loss of time, } \\
\text { wasted fuel and } \\
\text { vehicle emissions, } \\
\text { it means we can } \\
\text { save money by } \\
\text { providing smooth } \\
\text { flow of vehicles } \\
\text { Enhance beauty } \\
\text { Better flow of rain } \\
\text { water as well as }\end{array}$ \\
\hline
\end{tabular}

\begin{tabular}{|c|c|c|}
\hline $\begin{array}{l}\text { meter of } \\
\text { each side } \\
\text { of road } \\
\text { above } \\
\text { sewer } \\
\text { line. } \\
\text { 5. Fire } \\
\text { hydrant } \\
\text { with catch } \\
\text { basin for } \\
\text { storm } \\
\text { water at } \\
\text { every } 90 \\
\text { meter } \\
\text { distance. }\end{array}$ & & $\begin{array}{l}\text { sewer line waste } \\
\text { water. }\end{array}$ \\
\hline $\begin{array}{l}\text { PARKING } \\
\text { 1. At every } \\
100 \text { meter } \\
\text { distance } \\
\text { space for } \\
\text { public } \\
\text { vehicle } \\
\text { parking } \\
\text { 2. Marking } \\
\text { for parked } \\
\text { vehicle } \\
\text { using } \\
\text { paints or } \\
\text { electronic } \\
\text { linings. } \\
\text { Arrange } \\
\text { sensors for } \\
\text { the } \\
\text { deduction } \\
\text { and } \\
\text { information } \\
\text { of park } \\
\text { vehicles } \\
\text { through } \\
\text { IoT }\end{array}$ & $\begin{array}{l}\text { Cost } \\
\text { of } 20 \\
\text { sensor } \\
\text { s } \\
\text { installe } \\
\text { d after } \\
\text { every } \\
100 \\
\text { meter } \\
\text { distanc } \\
\text { e for } \\
\text { one } \\
\text { km } \\
\text { patch= } \\
20 \\
\text { lacks } \\
\text { of } \\
\text { rupees }\end{array}$ & $\begin{array}{l}\text { Smart Parking could } \\
\text { result in 2,20,000 } \\
\text { gallons of fuels saving } \\
\text { till } 2030 \text { and approx. } \\
3,00,000 \text { gallons of } \\
\text { fuels saved by } \\
\text { 2050(Smart parking) } \\
\text { - Smooth traffic } \\
\text { flows on road due } \\
\text { to the availability } \\
\text { of road side spaces } \\
\text { It guides residents } \\
\text { and visitors to } \\
\text { available parking } \\
\text { space to } \\
\text { Provide tools to } \\
\text { optimize work } \\
\text { force management }\end{array}$ \\
\hline $\begin{array}{l}\text { SEPARATE } \\
\text { MARKET } \\
\text { PLACE FOR } \\
\text { VENDORS } \\
\text { 1. The constructi } \\
\text { on of } \\
\text { temporary } \\
\text { shelters } \\
\text { for these } \\
\text { market } \\
\text { Connect } \\
\text { these } \\
\text { markets } \\
\text { through } \\
\text { mobile } \\
\text { based } \\
\text { applicatio } \\
\text { n service } \\
\text { for home }\end{array}$ & $\begin{array}{l}\text { No } \\
\text { direct } \\
\text { cost } \\
\text { involv } \\
\text { ed at } \\
\text { all. }\end{array}$ & 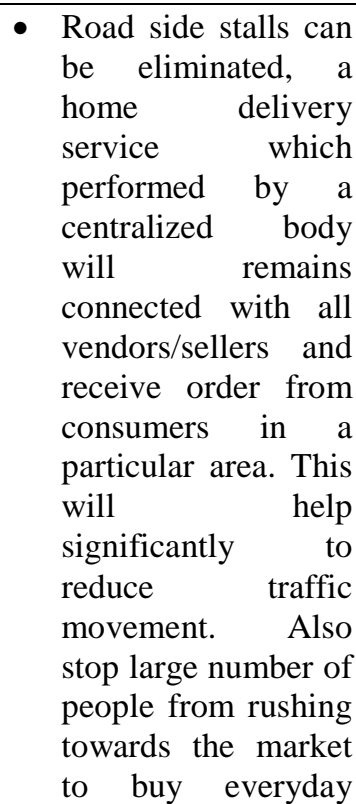 \\
\hline
\end{tabular}




\begin{tabular}{|c|c|c|}
\hline delivery. & & needs. \\
\hline $\begin{array}{l}\text { BATTERY } \\
\text { RICKSHAW } \\
\text { CHARGING } \\
\text { STATIONS } \\
\text { 1. Constructi } \\
\quad \text { on of } \\
\text { charging } \\
\text { station } \\
\text { with fast } \\
\text { chargers }\end{array}$ & $\begin{array}{l}20 \\
\text { level 1 } \\
\text { fast } \\
\text { charge } \\
\mathrm{r} \\
\text { approx } \\
\text {.cost } \\
=\quad 6 \\
\text { lacks( } \\
\text { Fast } \\
\text { charge } \\
\text { r cost). }\end{array}$ & 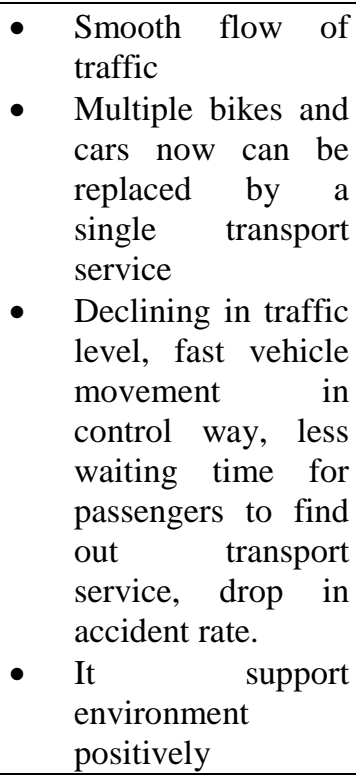 \\
\hline
\end{tabular}

\section{CONCLUSION}

The work presented in this paper is purely based on smart and sustainability management of traffic for Aligarh city. The analysis and results determine that if this management approach is carried out to modify whole city, undeniably it will function better by reason of time saving due to smooth flow of vehicles, lesser emission of harmful gases due to lesser time on road and the use of CNG/battery operated vehicles, additionally it will also save cost.

The new system of road enhances the beauty as well, which in result appearance of the city will be attractive. Smart ways of marketing and separate place for vendors proves a good management and reduction in rush on road.

\section{REFERENCES}

[1] T. Litman, "Evaluating Accessibility for Transportation Planning Measuring People's Ability To Reach Desired Goods and Activities," no. January 2015, p. 57, 2015.

[2] "Traffic Congestion." [Online]. Available: http://www.sice.com/en/news/smart-pedestriancrossing. [Accessed: 30-Dec-2016].

[3] K. Mandal, A. Sen, A. Chakraborty, S. Roy, S. Batabyal, and S. Bandyopadhyay, "Road traffic congestion monitoring and measurement using active RFID and GSM technology," 2011 14th Int. IEEE Conf. Intell. Transp. Syst., pp. 1375-1379, 2011.

[4] G. R. Grob and E. S. Iseo, "Future Transportation with Smart Grids \&Sustainable Energy Chairman ISO Committee on Energy Systems Analyses and Statistics," 2009.

[5] "Smart parking." [Online]. Available: http://www.happiestminds.com/whitepapers/smartparking.pdf. [Accessed: 10-Dec-2016].
[6] "Transportation." [Online]. Available: http://smartcitiescouncil.com/smart-citiesinformation-center/transportation.

[7] K. Singh and N. Sharma, "Smart cities in India: key areas and challenges - case study of Chandigarh," IJMSS, vol. 4, no. 1, pp. 386-396, 2016.

[8] “Cost per metre road." [Online]. Available: http://www.barrie.ca/assets/engineering/nov2010/App endix L - Costs per metre.pdf.

[9] "Fast charger cost.".

\section{BIOGRAPHIES}

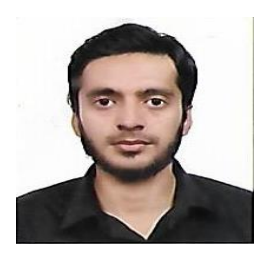

M Yasir Khan is a Master's student at Al-Falah University. He has published two research papers in journal and conference. His research interests include construction planning and management, traffic management, sustainable smart city. Currently, he is working on the development of a model of an internal transport system for Aligarh city.

Dr. M. Saad Alam received the B. Tech. degree in electrical engineering from the Aligarh Muslim University, Aligarh, India, in 2003, and the M.S. in electrical and computer engineering with specialization in energy, environment and economics from the Illinois Institute of Technology, Chicago, IL, USA, in 2005. He has also obtained his $\mathrm{PhD}$ in electrical engineering in 2009 from Tennessee Tech University, USA. He was also listed on Bristol Who's Who and Madison Who's Who among Professionals and Executives in 2011 and on Mont Clair Who's Who among Collegiate Faculty in 2012.Currently, he is leading the Industrial collaborative Inter-disciplinary research in electric mobility and is the Coordinator of the Center of Advanced Research in Electrified Transportation (CARET) of AMU.

Mohd Kamil Vakil is a Master's student at Aligarh Muslim University. He has published two research papers in journal and conference. His research interests include grey water treatment, air quality control, heavy metals treatment in ground water and sustainable development of nonmetropolitan cities. Currently, he is working on grey water treatment fit for drinking purpose and heavy metals contamination in ground water.

Abdullah Talib is a Master's student at Indian Institute of Technology Delhi. He has done his B.Tech from Aligarh Muslim University. He has published three research paper in journal and conferences. His research interests include geotechnical engineering, tunnel engineering, rock mechanics, geo polymer concrete, construction management and waste water treatment. Currently, he is working on squeezing phenomena in the Himalayan tunnels, management of grey water and urbanization of the transport system. 